\title{
Elülső feltárásból végzett minimál invazív csípőprotézis beültetéssel szerzett kezdeti tapasztalatok
}

\author{
DR. DE JONGE TAMÁS, DR. KELEMEN PÉTER, DR. PAUKA DEMETER, \\ DR. TORKOS MIKLÓS BULCSÚ
}

\section{ÖSSZEFOGLALÁS}

Az elmúlt másfél évtizedben világszerte egyre népszerúbbé vált a direkt anterior feltárásból végzett csípőízületi totál endoprotézis beültetés. A módszernek a korai posztoperatív időszakban tapasztalható egyértelmű előnyeit könnyen meghiúsíthatják az esetleges szövődmények, amelyek gyakorisága különösen a betanulási időszakban igen magas is lehet. Jelen közleményben a szerzők az első 40 mútét tapasztalatairól és az észlelt komplikációkról számolnak be. A szövődmények közül a feltárás típusával egyértelműen összefüggésbe hozható volt egy mútéti kezelést igénylő vérömleny képződés és egy kimetszést igénylő felületes sebgyógyulási zavar, továbbá két esetben a nagytompor csúcsának következmény nélküli abruptióját is észlelték. Az irodalomban gyakran citált femurtest-törés, femur perforáció, implantátum malpozíció egyetlen esetben sem fordult elő. A szerzők megállapítják, a direkt anterior feltárás alkalmas a rutinszerűen végzett csípőprotézis beültetésre. Kellő felkészülést követően, gondos, óvatos és tudatos mútéti technika alkalmazásával jelentősen csökkenthető a szövődmények gyakorisága a betanulási időszakban is.

\section{Kulcsszavak: $\quad$ Arthroplastica, csípö; Csípöprotézis beültetés; Minimál invaziv ellátás;}

T. de Jonge, P. Kelemen, D. Pauka, M. B. Torkos: Initial experiences of total hip replacement through direct anterior approach

Total hip replacement through direct anterior approach became worldwide popular during the last fifteen years. The obvious advantages of this technique may be lost by complications mostly described with relation to the learning curve. The present paper details the authors' experience with the first 40 operated cases. Among the complications related to the type of the surgical approach there were one haematoma required surgical evacuation; one superficial wound healing problem treated with excision; two abruption of the tip of the greater trochanter, which were left untreated without any negative consequences. The often described femur shaft fracture, femur perforation or component malpositioning were not observed in any of the cases. Authors conclude that the direct anterior approach is a suitable one for routine hip replacement only after proper training and with careful and cautious surgical technique.

Key words: $\quad$ Arthroplasty, replacement, hip-Methods/Complications; Surgical procedures, minimally invasive - Methods/Complications; 


\section{BEVEZETÉS}

A direkt anterior feltárásból végzett csípőprotetikát egyre nagyobb érdeklődés övezi, a témával kapcsolatosan fellelhető közlemények száma az utóbbi években ugrásszerűen megnövekedett. A módszer megítélése azonban közel sem egységes. A feltárás rövidtávú előnyei egyértelműek $(1,2,6,17,21,24)$. Aggasztó azonban a magas szövődményráta (9, $10,13,14,25)$, amely a kritikusok szerint nincs arányban a módszer biztosította előnyökkel. Az ellenzők szerint a közvetlen posztoperatív szakban gyorsabb a betegek felépülése, de a 6 hetes -3 hónapos utánkövetések már nem igazolják, hogy bármi pozitív hozadéka lenne az elülső feltárásnak $(7,24)$. Ezzel szemben Restrepo és Parvizi munkacsoportja számos szempontot figyelembe véve hasonlította össze az elülső feltárást a direkt lateralis behatolással. Szignifikánsan jobbnak ítélték meg az előbbit mind a 6 hetes, 6 hónapos sőt az 1 éves utánvizsgálatok során, de a 2 éves kontrollvizsgálat idején már kiegyenlítődtek a különbségek (21).

Szombathelyen a Markusovszky Egyetemi Oktatókórház Ortopédiai Sebészeti Osztályán a csípőprotetika bevezetése óta a direkt lateralis behatolás volt a rutinszerúen alkalmazott technika. Az utóbbi 15 évben folyamatosan tökéletesítettük módszerünket: a „szükséges de elegendő" elvet szem előtt tartva minimalizáltuk a feltárást, bevezettük a betegek korai mobilizálását, műanyag cementdugó, cementpuska és cementkompresszió alkalmazásával tökéletesítettük cementezési technikánkat, gyógyszeres vérzéscsillapítással lecsökkentettük a vérveszteséget és a transzfúziós igényt (11), multimodális fájdalomcsillapítás keretében alkalmazott helyi infiltrációs analgéziával pedig elviselhetőbbé tettük a betegek közvetlen műtét utáni fájdalmait (12). Mindezek ellenére úgy éreztük, betegeink felépülése nem kellő ütemben halad, nehezen hagyják el a segédeszközt, lassan tér vissza az abduktorok izomereje. Ez sarkallt bennünket arra, hogy más típusú feltárást válasszunk, amellyel elkerülhető a direkt lateralis behatolás során elvégzett részleges elülső abductor leválasztás, továbbá kiküszöbölhető a nervus gluteus superior kompressziós sérülésének potenciális lehetősége.
Hazánkban Szabó István nevéhez füződik a direkt anterior feltárásból végzett csípőízületi teljes endoprotézis beültetés bevezetése (22, 23), mely módszer minimál invazivitása nem a feltárás méretéből, hanem lokalizációjából adódik: tisztán intermuscularis és interneuralis feltárás, azaz a nervus femoralis és a nervus gluteus superior ellátási területének a találkozási határzónájában történik a behatolás. $A$ csípőízület feltárásához nem szükséges izmokinak leválasztása vagy átvágása, vagy akár rostok közötti megnyitása, csupán eltartása. A feltárás akkor is minimál invazívnak minősül, ha nem mini bőrmetszésből történik a csípőízületre való ráhatolás.

Megfelelő felkészülést követően (többszöri mútői látogatás három különböző operatőrnél; bonctermi gyakorlatok; speciális mútéttani kurzus) 2016. május 30-án elvégeztük az első direkt anterior feltárásból végzett teljes csípőízületi endoprotézis beültetést. Jelen közleményünk célja, hogy bemutassuk a módszerrel szerzett kezdeti tapasztalatainkat, különös tekintettel a leginkább kritizált tényezőre: a betanulási időszak szövődményeire.

\section{ANYAG ÉS MÓDSZER}

2016. május 30. és 2017. március 30. között 40 esetben végeztünk direkt anterior feltárásból teljes csípőízületi endoprotézis beültetést. Tekintettel a betanulási időszakra, igyekeztünk kizárni a nehéz anatómiai viszonyokat (súlyos csípődysplasia vagy inveterált ficam, protrusio acetabuli, varusos csípő, erősen muscularis zömök testalkat, továbbá „kötényhas” jelenléte). Valamennyi mútétet egyazon operatőr végezte. A páciens pozicionálása: hanyattfekvés, medence kiemelése nélkül, hagyományos mútőasztalon, trakciós eszköz alkalmazása nélkül. A mútéti terület dezinficiálása és steril lepedőkkel történő izolálása hagyományosan, teljes mértékben a direkt laterális feltárásból végzett eseteknek megfelelően történt (azaz az ellenoldali alsó végtagot se nem mostuk le, se nem izoláltuk külön). A femoralis komponens előkészítésének és beültetésének fázisában a csípők hyperextenzióját a műtőasztal megtöretésével biztosítottuk. A beavatkozásnál egy asszisztens orvos és egy mútősnő segédkezett, önfeltáró rendszert minden esetben alkalmaztunk (1-3. ábrák). 
Előre meghatározott szempontok szerint rögzítettük a betegek adatait: életkor, nem, $\mathrm{BMI}$, coxarthrosis típusa, oldalisága, beültetett protézis típusa, mútét időtartama, mútét utáni vérzés mennyisége, a mobilizálás során a segédeszköz használat mikéntje; a posztoperatív röntgenfelvételeken a vápa meredeksége, a szárkomponens pozíciója. Feljegyeztük az esetleges szövődményeket, kialakulásuk idejét és azok ellátását. Az egyéves mútét utáni rutin kontrollvizsgálat során valamennyi betegnél fizikális vizsgálatot végeztünk, és összehasonlító AP, valamit az operált oldali csípő oldalirányú felvételét végeztettük el. Kerestük a panaszokat (még) nem okozó esetleges komplikációkra utaló jeleket.

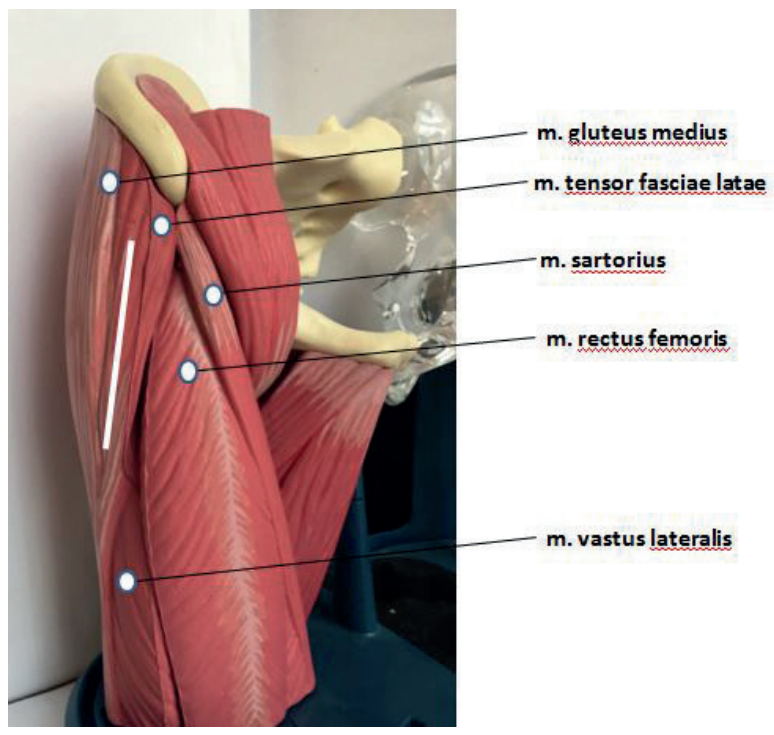

1. ábra

A bőrmetszés (világos egyenes vonallal jelölve) a m. tensor fasciae latae izomrostjaival párhuzamosan, az izomhas középső és lateralis harmadának határának megfelelően történik

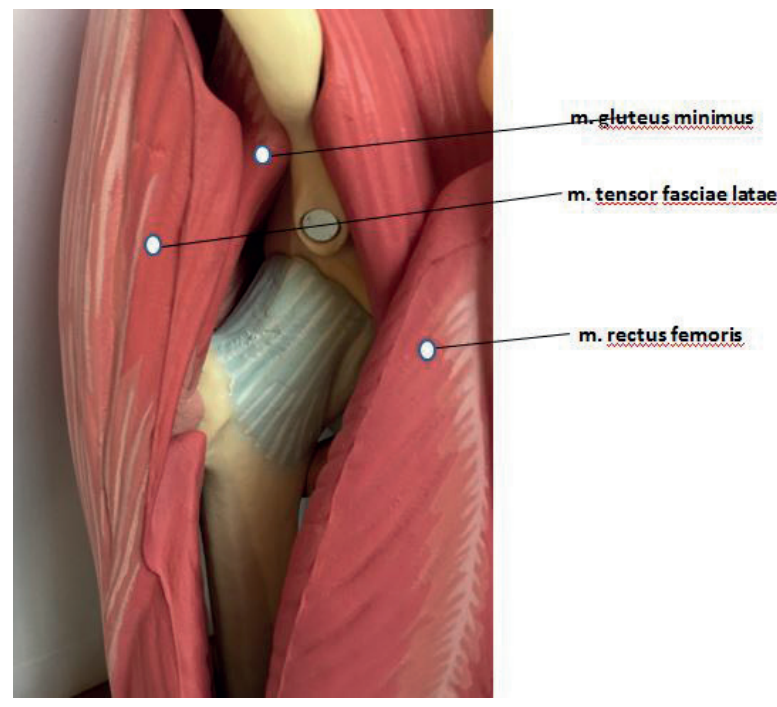

2. ábra

A tensor izmot lateral felé, a rectus femoris izmot medial felé eltartva a mélybe hatolva jutunk rá a csípőízületre 


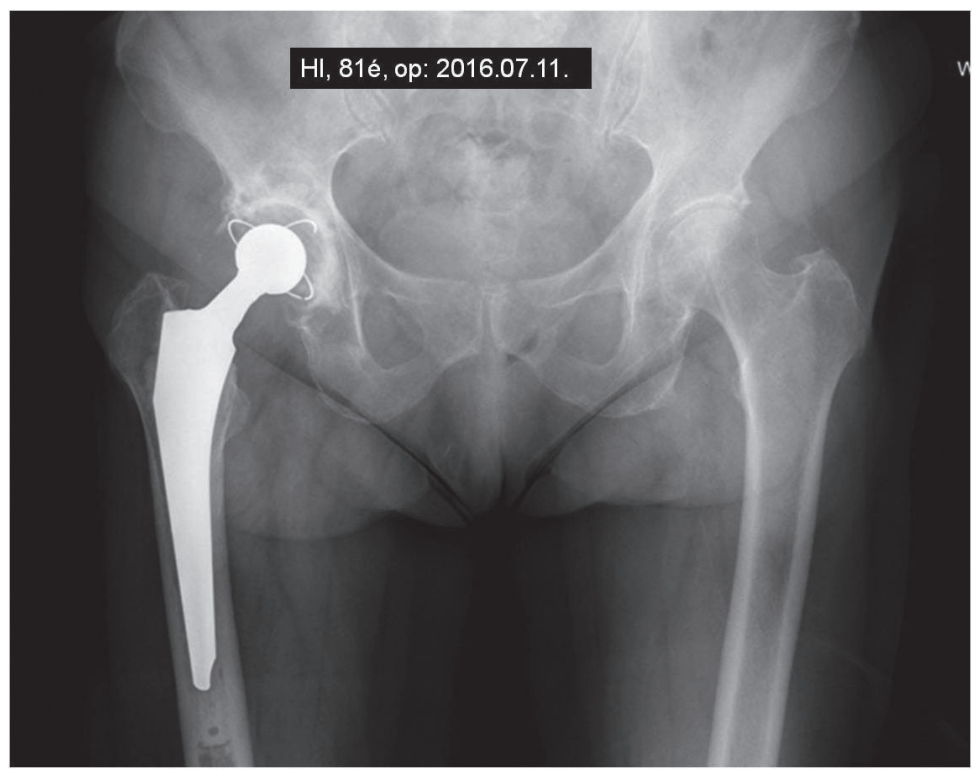

3. ábra

Elülső feltárásból beültetett cementes csípőprotézis röntgenképe

\section{EREDMÉNYEK}

2016. május 30. és 2017. március 30. között 39 beteg 40 csípőjének teljes protetizálását végeztük el direkt anterior feltárásból (29 nő, 10 férfi). $A z$ átlagos életkor a mútét idejében 67 (40-84) év, az átlagos BMI 28,6 (21,3-44,1) volt. A mútéti diagnózis 30 esetben primer coxarthrosis volt. A secunder coxarthrosisok hátterében 9 congenitalis csípődysplasia állt (8 esetben Crowe 1-es, 1 esetben Crowe 2-es típusú), 1 betegnél juvenilis chronicus arthritis talaján kialakult, de Crowe 2-es súlyosságú dysplasiás jeleket mutató arthrosis állt. 22 esetben jobb oldali, 18 esetben bal oldali volt az elváltozás. A mútétek során 17 esetben cementes, 21 esetben cement nélküli implantátumot használtunk, 1 esetben hibrid, 1 esetben reverz hibrid protézis beültetése jelentette a megoldást. A mútétek időtartama átlagosan 102 (70-150) perc volt, az első 48 óra folyamán a dréneken ürült vér mennyisége átlagosan 452 (100-1500) ml-nek adódott. A közvetlen posztoperatív röntgenfelvételeken kimért vápaszög átlagosan 48 (33-61) fok volt, a femoralis komponensek pozíciója 2 esetben minimális varus tengelyeltérést mutatott, amelynek mértéke 5 fok, illetve 6 fok volt.

A betegek mobilizálását a mútétet követő napon gyógytornász végezte. 30 beteg a mútét utáni 1. nap délutánján egy könyökmankóval járóképes volt, teljes mértékben önellátó. További 8 beteg a következő napra vált önellátóvá. Öt beteg a posztoperatív 4. napon már segédeszköz nélkül fennjárt. Két beteg tartósan használta a járókeretet.

\section{KOMPLIKÁCIÓK}

Felületes sebgyógyulási zavar 1 esetben fordult elő, sebkimetszést és resuturát végeztünk, intravénás antibiotikus terápiával kiegészítve. Feltárást igénylő vérömleny szintén 1 esetben alakult ki. Ellátást igénylő csonttörés nem fordult elő, de a nagytompor csúcsi részének abruptiója 2 esetben intraoperatíve következett be: mindkét betegnél a helytelenül behelyezett Hohmann-retraktor volt a iatrogén sérülés oka. A sérülés egyik esetben sem vált okozójává, sem krónikus fájdalomnak, sem sántításnak.

Szeptikus szövődményt 1 esetben észleltünk: 3 héttel a mútét után akut korai infekció jelei miatt feltárást, debridment-t és a fejkomponens cseréjét végeztük el a protézis megtartásával, 2 hetes intravénás, majd 10 hetes per os antibiotikus kezeléssel kombinálva. A páciens jelen közlemény írásakor is panasz- és tünetmentes. 
Protézis luxatio 2 esetben fordult elő, mindkét esetben relatíve későn jelentkezett a szövődmény, korrekt implantátum pozíció mellett: 75 éves nőbetegnél 9 hónappal a mútét után hyperextenziós mozdulatra következett be az elülső ficam, amely 3 hónap múlva ismétlődött. A polietilén vápaperem elülső toldásával stabilizáltuk a múvi ízületet; a másik esetben 84 éves nőbeteget 6 hónappal a beültetést követően vettük fel hátsó protézis ficam miatt, korrekt implantátum pozíció mellett. Fedett repozíciót követően 2 hónappal ismételten ficamodott protézise. Narcosisban történt vizsgálat során multidirekcionális instabilitást észleltünk. Feltárás mellett döntöttünk, megfelelő nyakhosszúságú fejkomponens cseréjével a stabilitást sikerült helyreállítani. Azóta nem ficamodott a csípője.

A nervus cutaneus femoris lateralis beidegzési területének megfelelően a betegek felénél jelentkezett hypaesthesia. A 3 hónapos kontrollvizsgálat során az érzészavar már enyhe fokú volt, a betegeket nem zavarta: 1 beteg panaszolta magától a fonákérzést, a többi 19 beteg csak rákérdezésre említette meg az érzészavart. Egy évvel a mútét után 19 betegnél helyreállt az érzéskvalitás, 1 beteg továbbra is gyengébb érzésről számolt be a hegtől lateralisan. Az egyéves utánkövetéssel elvégzett vizsgálat során szövődményre utaló jeleket egyetlen esetben sem észleltünk (I. táblázat) (4-7. ábrák).

\section{I. táblázat Az első 40 mütét során észlelt szövődmények}

\begin{tabular}{|c|c|c|c|c|c|}
\hline \multirow{2}{*}{ Varusos szár } & \multicolumn{3}{|c|}{ Femur fractura } & \multicolumn{2}{c}{ Vérzés } \\
\hline & $\begin{array}{c}\text { trochanter } \\
\text { csúcs }\end{array}$ & calcar & diaphysis & minor & maior \\
\hline 2 & 2 & 0 & 0 & 1 & 1 \\
\hline Sebgyógyulási zavar & $\begin{array}{c}\text { Korai } \\
\text { mélyinfekció }\end{array}$ & Luxatio & Hypaesthesia \\
\hline 1 & 1 & 2 & 20 \\
\hline
\end{tabular}

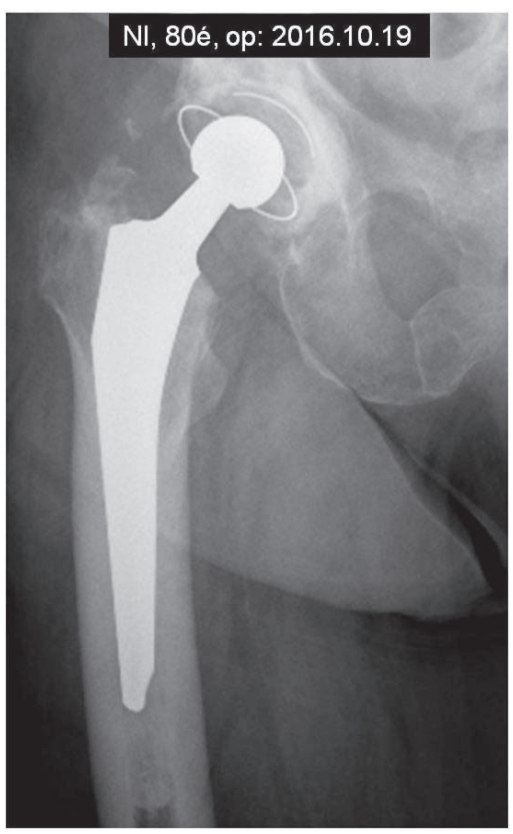

4. ábra

Intraoperatív szövődmény. A nagytompor csúcsának sérülése, amely ellátást nem igényelt, a beteg panaszmentes 


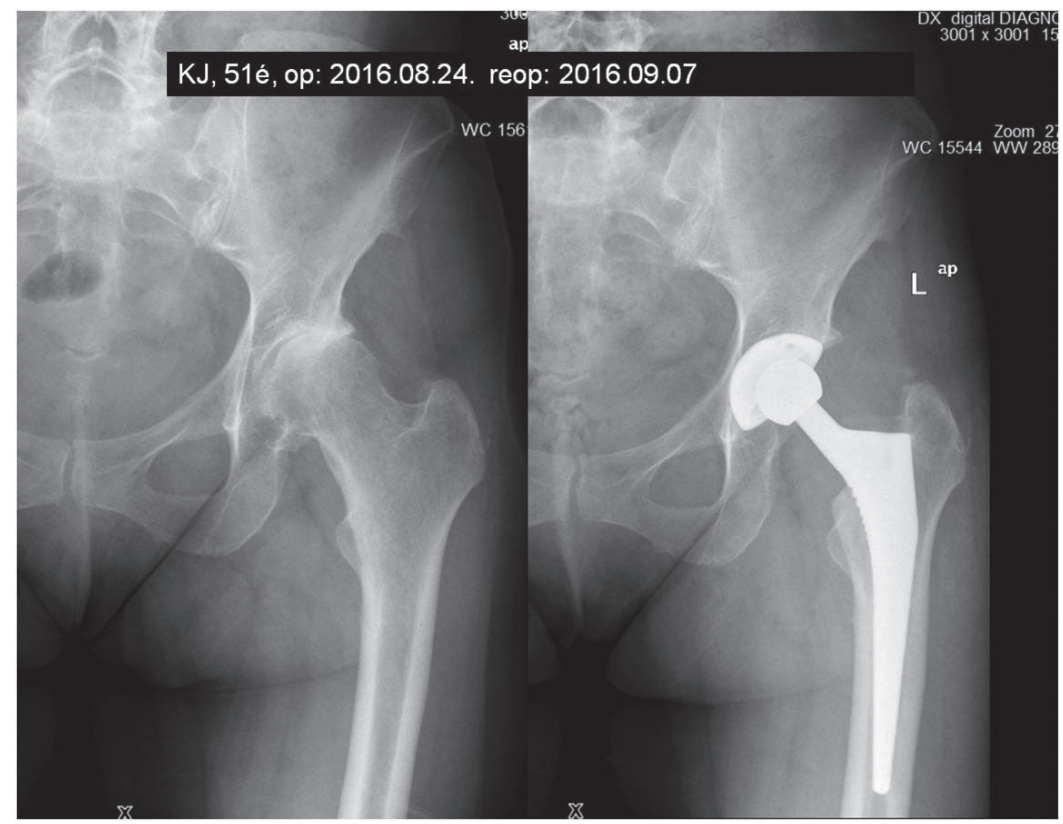

\section{5. ábra}

Crowe 1-es típusú displasiás csipő. Két héttel a protézis beültetését követően a kialakult vérömleny mútéti feltárást és kiürítést igényelt

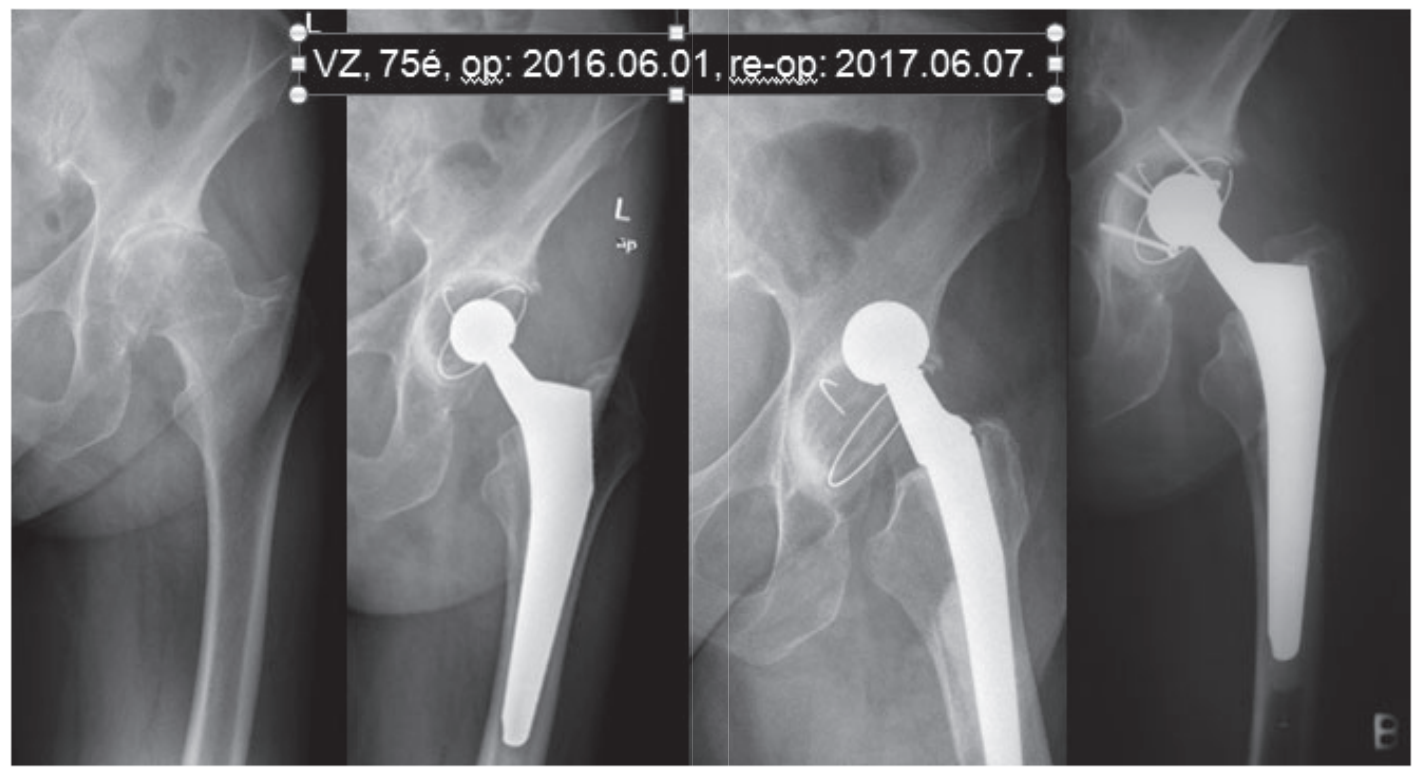

\section{6. ábra}

9 hónappal, majd 12 hónappal a beültetést követöen elülsö ficam következett be hyperextenziós mozdulatra. Elülső vápaperem augmentatio jelentette a megoldást 

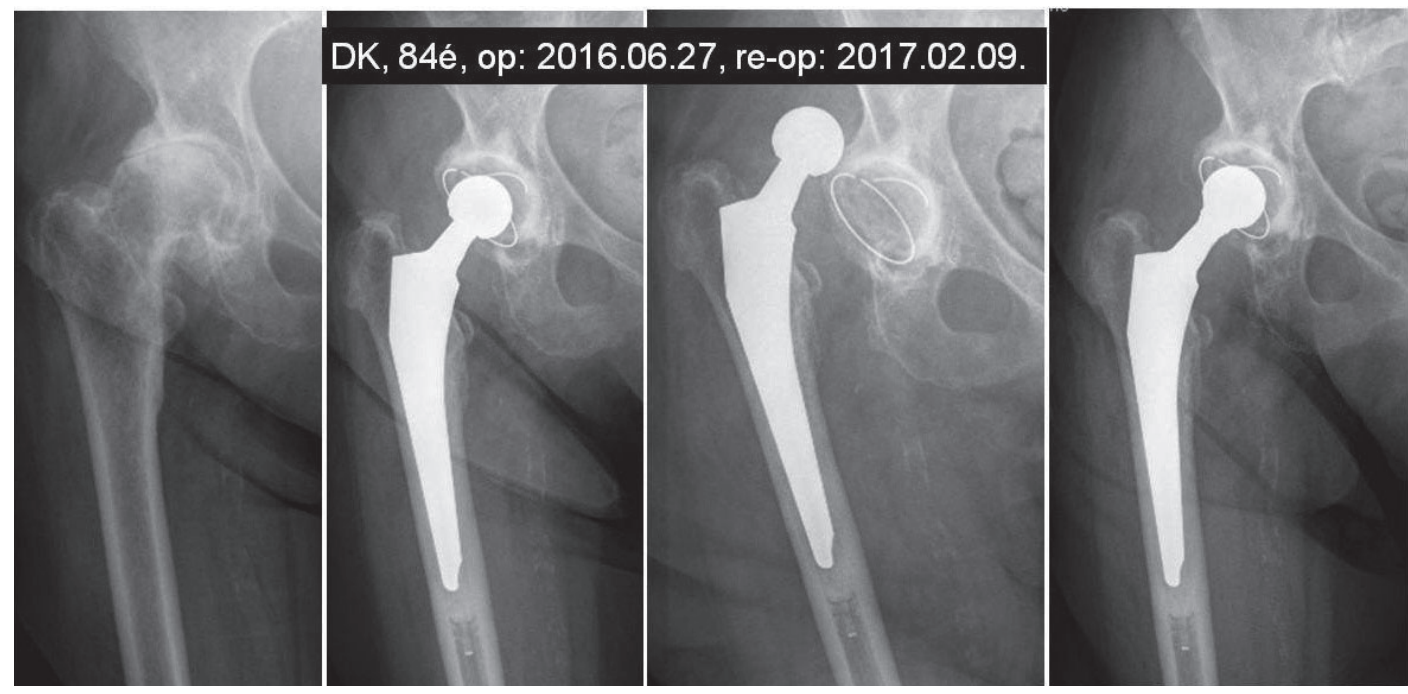

7. ábra

6 hónappal, majd 8 hónappal a primer mütét után következett be a protézis ficama. A multidirekcionális instabilitást két mérettel hosszabb fejkomponens cseréjével szüntettük meg

\section{MEGBESZÉLÉS}

A nagyízületi endoprotetikában a minimál invazivitásnak körülbelül 15 éves hagyománya van már Magyarországon (4-6). Míg a laikusok szemében a minimál invazivitás elsősorban a mútéti metszés, illetve a visszamaradó heg hosszában mérhető, addig sebészi szemmel nézve a bőr szintjénél mélyebben fekvő szövetek sérülése, roncsolása mértékének csökkentését és a minél gyorsabb felépülést tekintjük mérvadónak. Csípőprotézis esetében, ha egyébként ugyanazt az eljárást követjük, a mini bőrmetszésből önmagában még nem következik a kisebb vérveszteség vagy a gyorsabb rehabilitáció (26). A beteg gyorsabb felépülését tehát nem a bőrmetszés hossza gátolja elsősorban, hanem az izmok sérülése, az izmok beidegzésének károsodása. Ez lehet a mútéti feltárás részeként végzett izomátvágás, izomtapadás leválasztás, de lehet a retraktorok által okozott izomrost roncsolódás és mozgató idegrost neuropraxia is. Természetesen a páciensek mútét előtti általános állapota, erőnléte, izomstátusza is meghatározó jelentőségű a mútét utáni funkció szempontjából. Minél kisebb az operált csípőízület funkciója szempontjából kritikus jelentőségű izmok (és azok beidegzésének) mútéti sérülése, annál inkább beszélhetünk minimál invazivitásról. A számos minimál invazív csípőprotézis beültetési technikák közül az elülső feltárásból végzett mútét tisztán intermuscularis és interneuralis módszernek tartott eljárás: nem izomrostok között, hanem izmok közötti kötőszövetes sövények mentén történik a mútéti behatolás, mégpedig a nervus gluteus és a nervus femoralis idegek motoros ágrendszerének határterületén: a feltárásnak ezt az interneuralis mivoltát tartják a legfontosabb tényezőnek a mozgató idegágak intraoperatív kompressziós sérülési lehetőségének minimalizálása szempontjából. Nem károsodnak sem az izmok, sem az ellátó idegek, a csípőízület stabilitásáért és aktív abductiójáért felelős izmok sértetlenül maradnak.

A direkt anterior feltárásból végzett csípőprotézis implantációnak a legnehezebb része a femur „bemenet” tengelyirányban történő hozzáférésének a biztosítása. Az ehhez szükséges lágyrész felszabadítás mellett a végtag megfelelő pozicionálása céljából egy speciális trakciós készülékbe helyezik az operált alsó végtagot (19). Ennek segítségével billenthető előre a csonkolt proximalis femurvég, s lehet tengelyirányban hozzáférni az elülső feltáráson keresztül a meta-diafízishez. Meglátásunk szerint az elülső feltárásból végzett csípőprotézis beültetések hazai szélesebb körű elterjedésének a trakciós készülék jelentette a legnagyobb akadályát: magas a beszerzési költsége, nem adaptálható minden mútőasztalhoz, megfelelő kezelése külön betanulási 
folyamatot igényel, mind az operáló orvos, mind a mútőssegéd részéről. $A$ múvi ízület stabilitásának vizsgálata és a végtaghossz pontos megítélése is nehezebb a trakciós készülékben rögzített alsó végtag esetében. A legmagasabb femurtöréses szövődményrátát bemutató közlemények is trakciós asztalon végzett mútétek kiértékelése során születtek (25).

A „trakciós asztal nélküli” technika megjelenésével lehetőség nyílt a húzókészülék mellőzésére $(8,18,19)$. Feltétele azonban, hogy a mútőasztal Trendelenburg helyzetbe dönthető legyen, s a csípőízület szintjében hyperextenzióba megtörethető legyen. Praktikussági szempontokból fontosnak tartjuk, hogy mindez gombnyomásra motorizáltan elvégezhető legyen. További mútéttechnikai finomítás eredményeként a nagy tapasztalattal rendelkező operatőrök a mútőasztal megtöretése nélkül is elvégzik a beavatkozást.

Bármelyik technikát is választjuk, a direkt anterior feltárásból végzett csípőprotézis beültetés végzése komoly előzetes felkészülési folyamatot igényel. Ennek figyelmen kívül hagyása minden bizonnyal magas szövődményrátát hoz magával. Maga az elülső feltárás is rejt magában néhány buktatót, de könynyen elsajátítható. A proximalis femurvégen insufficiens módon végzett lágyrész felszabadításnak már súlyos következményei lehetnek: malpozícióban álló femoralis komponens, de akár a combcsont perforációja és/vagy törése is.

A betanulási időszakkal kapcsolatban az irodalomban megjelent magasabb szövődményráta $(3,13,16,20,25)$ véleményünk szerint azonban nem magában az elülső feltárásban keresendő. Azok az operatőrök, akik korábban oldalfektetésben ültettek be csípőprotézist (akár anterolateralis, akár posterolateralis behatolásból), egy új helyzettel találták szemben magukat: a páciens hanyatt fektetése és az elölről végzett feltárás egy teljesen más mütéti szituációt jelent a sebész számára. Más a rálátás az ízületre, mások a referenciapontok, mások az irányok, gyakorlatilag minden más, mint amit korábban megszoktak. Így kezdetben magasabb a szövődményráta is. Ezzel szemben mi Magyarországon szerencsés helyzetben vagyunk: hanyatt fektetésben és lateralis vagy anterolateralis behatolásból ültetjük be a legtöbben a csípőprotézist. Az elülső feltárás során az ízületre való rálátás szempontjából számunkra szinte semmi se változik. Sőt, az acetabulumra való rálátás még jobb is. De a referenciapontok, irányok is mind-mind ugyanazok, mint az egyébként megszokott (lateralis, anterolateralis) feltárások során.

Jelen közleményben a vizsgálatba bevont első 40 eset tapasztalatai is ezt támasztják alá. Egyértelműen az elülső feltárással kapcsolatba hozható maior szövődmény nem fordult elő. A két ficamos eset kétségkívül súlyos szövődményként értékelendő, de mind a kettő teljesen korrekt implantátum pozícionálás mellett következett be, 6, illetve 9 hónappal a beültetést követően. Az akut szeptikus szövődmény szintén nem róható fel a feltárás rovására. Az 5 , illetve 6 fokos varus állású szárkomponens esetében nem tudjuk kizárni, hogy a feltárásból (és a kezdeti technikai nehézségekből) adódó nehezebb hozzáférhetőség eredményezte az egyébként minimális mértékű malpozíciót, de hasonló elhanyagolható mértékű varus állást más feltárások esetén is látunk. A feltárást igénylő haematoma már inkább írható az elülső feltárás betanulási időszakának a számlájára. Egyrészről az arteria circumflexa femoris anterior ágrendszerének nem megfelelő ellátása okozhat ilyen mértékű haematomát, de a proximalis femurvégen a még nem megfelelő gyakorlattal végzett lágyrészfelszabadítás is okozója lehet komolyabb utóvérzésnek.

Az elülső bőrmetszés sebgyógyulási zavara gyakrabban fordul elő (13), ezt egy esetben mi is észleltük. Az elülső hosszanti bőrmetszés okozta sebgyógyulási zavarok kivédhetők az inguinalis bőrredővel párhuzamosan vezetett bőrmetszéssel (bikini metszés), de ez a betanulási időszakban még nem javasolt, nagyobb tapasztalattal rendelkező operatőrök már ezt végzik. Mindenesetre célszerű kerülni az elülső feltárást a mútéti területre rálógó „kötényhas” megléte esetén $(9,13)$.

A nervus cutaneus femoris lateralis ellátási területén kialakuló hypaesthesia egyértelműen hátránya a módszernek, de saját tapasztalataink szerint nem zavarja a betegeket, s egy évvel a mútét után regrediálnak a tünetek (7, 15). A nervus cutaneus femoris lateralis területének hypaesthesiája kellően kíméletes mútéti technikával csökkenthető: lateralisabban vezetett bőrmetszés, kellő távolságot tartva az elülső felső csípőtövistől; a feltárás során, 
a szorosan a fascia lata felszínén futó idegágak esetenként látótérbe kerülnek, ilyenkor óvatos mobilizálás után eltarthatók; a fascia zárása során a lehető legkevesebbet kell csak a fasciából felölteni, így minimalizálható annak esélye, hogy egy idegág is felöltésre kerül.

Ugyan közleményünket elsősorban a betanulási időszak szövődményeire hegyeztük ki, nem mehetünk el szó nélkül a módszer egyértelmű előnyei mellett. A minimál invazív beavatkozások célja a betegek gyorsabb felépülése, a rehabilitációs szak lerövidítése, a még aktív dolgozók számára a munkába való visszatérés mihamarabbi lehetővé tétele. A mútét létjogosultsága nem csak azon mérhető le, hogy a beteg gyorsabban mobilizálható, csekélyebb a segédeszköz igénye, hanem a nővéri ápolási igény csökkenésén is. A 24-36 óra alatt önállóvá váló beteg alig igényel nővéri segítséget, mely által jelentős nővéri kapacitás szabadul fel. A sajnálatos módon manapság egyre égetőbb nővérhiány idején ezt rendkívül fontos hozadékának tartjuk az elülső feltárásból végzett csípőízületi endoprotetikának.

A legtöbb közlemény állásfoglalása szerint a háromhónapos utánkövetéssel elvégzett öszszehasonlító vizsgálatok nem mutatnak különbséget az egyéb módszerrel operált betegekhez képest $(7,24)$, bár akadnak ellenvélemények is (21). Mi magunk azt valljuk, megéri a befektetést és az erőfeszítést, hogy a betegek számára a gyógyulás és rehabilitáció első 6-12 hetét valóban megkönnyítsük.

A módszer betanulási időszakában értelemszerüen javasolt a megfelelő betegszelekció (19). Célszerű figyelembe venni a beteg alkatát. A magas BMI önmagában nem jelent relatív ellenjavallatot sem. Sőt, obes betegek esetében az elülső feltárás inkább előnyös, mert a combtő területén elöl mindig jóval vékonyabb a bőr alatti zsírréteg, mint akár oldalt, akár anterolateralisan. Inkább a zömök, erős, kötött izomzatú férfibetegek kerülendők kezdetben. A testalkat mellett a röntgenfelvételek kiértékelése során a csípő-medence konfigurációra is célszerű tekintettel lenni: a collodyaphysealis szög, továbbá a nagytompor - spina iliaca anterior superior távolság a betegválasztást befolyásoló tényezők. Ideális az enyhén valgusos csípő és hogy minél nagyobb tér legyen a nagytompor csúcsa és az elülső felső csípőtövis között (19).

A minimál invazív feltárásokat ellenzők gyakran érvelnek azzal, hogy korlátozottak a rálátási lehetőségek a mútéti területre. Hangsúlyozzuk, hogy a direkt anterior feltárás esetében nem szükségszerűen mini incízióból valósul meg a protézis beültetése, s egyáltalán nem korlátozott a rálátás a csípőízületre. Sőt, a vápa esetén egyértelműen jobbnak ítéljük meg a láthatóságot, a femur esetében pedig ugyanolyan jó, mint az anterolateralis, vagy a direkt lateralis feltárás esetében (megfelelően kivitelezett proximalis lágyrészfelszabadítást feltételezve).

Közleményünket figyelemfelhívó célzattal írtuk. Eredményeinkkel szeretnénk alátámasztani, hogy kellő előtanulmányokat és felkészülést követően, válogatott beteganyagon elkezdve, a direkt anterior feltárásból végzett csípőprotézis beültetés egyértelműen jó eredményekkel alkalmazható módszer, amelynek a betanulási időszakban sem magas a szövődményrátája.

\section{IRODALOM}

1. Agten C. A., Sutter R., Dora C., Pfirrmann C. W.: MR imaging of soft tissue alterations after total hip arthroplasty: comparison of classic surgical approaches. Eur. Radiol. 2017. 27. (3): 1312-1321. https://doi.org/10.1007/s00330-016-4455-7

2. Bergin P. F., Doppelt J. D., Kephart C. J., Benke M. T., Graeter J. H., Holmes A. S., Haleem-Smith H., Tuan R. S., Unger A. S.: Comparison of minimally invasive direct anterior versus posterior total hip arthroplasty based on inflammation and muscle damage markers. J. Bone Joint Surg. Am. 2011. 93: 1392-1398. https://doi.org/10.2106/JBJS.J.00557

3. Bhandari M., Matta J. M., Dodgin D., Clark C., Kregor P., Bradley G., Little L.: Outcomes following the single-incision anterior approach to total hip arthroplasty: a multicenter observational study. Orthop. Clin. North. Am. 2009. 40. (3): 329342. https://doi.org/10.1016/i.ocl.2009.03.001

4. Bucsi L., Dobos F., Sillinger T.: Az „egy metszéses” minimál invazív csípő totál endoprotézis mütétjének korai tapasztalatai osztályunkon. Magyar Traumatológia Ortopédia Kézsebészet Plasztikai Sebészet, 2004. 47. (4): 274-280.

5. Bucsi L., Dobos F.: A mütéti feltárásaink minimalizálása totál csípő- és térdprotézisek beültetése során. Magyar Traumatológia Ortopédia Kézsebészet Plasztikai Sebészet, 2009. 52. (2): 125-130.

6. Bucsi L., Kandár Z.: Minimál invazív direkt lateralis feltárásból beültetett totál csípő endoprotézis mütétek radiológiai elemzése. Magyar Traumatológia Ortopédia Kézsebészet Plasztikai Sebészet, 2006. 49. (3): 236-241. 
7. Cheng T. E., Wallis J. A., Taylor N. F., Holden C. T., Marks P., Smith C. L., Armstrong M. S., Singh P. J.: A Prospective randomized clinical trial in total hip arthroplasty - comparing early results between the direct anterior approach and the posterior approach. J. Arthroplasty. 2017. 32. (3): 883-890. https://doi.org/10.1016/i.arth.2016.08.027

8. Connolly K. P., Kamath A. F.: Direct anterior total hip arthroplasty: Literature review of variations in surgical technique. World J. Orthop. 2016. 7. (1): 38-43. https://doi.org/10.5312/wjo.v7.i1.38

9. Connolly K. P., Kamath A. F.: Direct anterior total hip arthroplasty: Comparative outcomes and contemporary results. World J Orthop. 2016. 7. (2): 94-101. https://doi.org/10.5312/wjo.v7.i2.94

10. De Geest T., Vansintjan P., De Loore G.: Direct anterior total hip arthroplasty: complications and early outcome in a series of 300 cases. Acta Orthop. Belg. 2013. 79. (2): 166-173.

11. de Jonge T.: Gyógyszeres vérzéscsillapitás csípöízületi endoprotézis-beültetések során. Orv. Hetil. 2012. $153: 1607-1612$. https://doi.org/10.1556/OH.2012.29455

12. de Jonge, T., Görgényi, Sz., Szabó, G., Torkos, M. B.: Helyi infiltrációs érzéstelenítés alkalmazása nagyízületi endoprotézisek beültetése során. Orv. Hetil. 2017. 158. (9): 351-356. https://doi.org/10.1556/650.2017.30666

13. Jewett B. A., Collis D. K.: High Complication Rate With Anterior total hip arthroplasties on a fracture table. Clin. Orthop. Relat. Res. 2011. 469. (2): 503-507. https://doi.org/10.1007/s11999-010-1568-1

14. Lee G. C., Marconi D.: Complications following direct anterior hip procedures: costs to both patients and surgeons. J. Arthroplasty. 2015. 30. 9. Suppl. 98-101.

15. Macheras G. A., Christofilopoulos P., Lepetsos P., Leonidou A. O., Anastasopoulos P. P., Galanakos S. P.: Nerve injuries in total hip arthroplasty with a mini invasive anterior approach. Hip Int. 2016. 26. (4): $338-343$. https://doi.org/10.5301/hipint.5000352

16. Masonis J., Thompson C., Odum S.: Safe and accurate: learning the direct anterior total hip arthroplasty. Orthopedics. 2008. 31. 12. Suppl. 2.

17. Mayr E., Nogler M., Benedetti M. G., Kessler O., Reinthaler A., Krismer M., Leardini A.: A prospective randomized assessment of earlier functional recovery in THA patients treated by minimally invasive direct anterior approach: a gait analysis study. Clin. Biomech. 2009. 24. (10): 812-818. https://doi.org/10.1016/j.clinbiomech.2009.07.010

18. Molenaers B., Driesen R., Molenaers G., Corten K.: The direct anterior approach for complex primary total hip arthroplasty: the extensile acetabular approach on a regular operating room table. J. Arthroplasty. 2017. 32. (5): $1553-1559$. https://doi.org/10.1016/i.arth.2016.12.016

19. Moskal J. T., Capps S. G., Scanelli J. A.: Anterior muscle sparing approach for total hip arthroplasty. World J. Orthop. 2013. 4. (1): 12-18. https://doi.org/10.5312/wjo.v4.i1.12

20. Post Z. D., Orozco F., Diaz-Ledezma C., Hozack W. J., Ong A.: Direct anterior approach for total hip arthroplasty: indications, technique, and results. J. Am. Acad. Orthop. Surg. 2014. 22. (9): 595-603. https://doi.org/10.5435/JAAOS-22-09-595

21. Restrepo C., Parvizi J., Pour A. E., Hozack W. J.: Prospective randomized study of two surgical approaches for total hip arthroplasty. J. Arthroplasty. 2010. 25. (5): 671-679. https://doi.org/10.1016/i.arth.2010.02.002

22. Szabó I., Tóth Z., Palotás A., Henics D., Gimesi Cs., Torkos M.: A csípöprotézis beültetés leggyakoribb feltárásai. Fizioterápia. 2011. 20. (4): 18-22.

23. Torkos M. B., Gimesi C., Tóth Z., Bajzik G., Magyar Á., Szabó l.: Comparative results of half year follow-up after primary total hip arthroplasty with minimally invasive anterior and direct lateral approach. J. Bone Joint Surg. 2012. 94-B. Suppl. $37: 124$.

24. Wesseling M., Meyer C., Corten K., Simon J. P., Desloovere K., Jonkers I.: Does surgical approach or prosthesis type affect hip joint loading one year after surgery? Gait Posture. 2016. 44: 74-82. https://doi.org/10.1016/i.gaitpost.2015.11.009

25. Woolson S. T., Mow C. S., Syquia J. F., Lannin J. V., Schurman D. J.: Comparison of primary total hip replacements with a standard incision or a mini-incision. J. Bone Joint Surg. Am. 2004. 86: $1353-1358$. https://doi.org/10.2106/00004623-200407000-00001

26. Woolson S. T., Pouliot M. A., Huddleston J. I.: Primary total hip arthroplasty using an anterior approach and a fracture table: short-term results from a community hospital. J. Arthroplasty. 2009. 24. (7): 999-1005. https://doi.org/10.1016/i.arth.2009.04.001

\section{Dr. de Jonge Tamás}

Markusovszky Egyetemi Oktatókórház

Ortopédiai Sebészeti Osztály

9700 Szombathely, Markusovszky u. 5.

E-mail: dejonge.tamas@markusovszky.hu 